\title{
Behavior of Experimental Zinc-Steel Couples Underground
}

\begin{abstract}
By Irving A. Denison and Melvin Romanoff
The behavior of zinc anodes for the protection of iron and steel eathodically was investigated in eight diverse soil environments. The experimental unit consisted of a small steel ring to which was connected from one to three zinc cylinders to provide different area ratios of zinc to steel. Corrosion of the steel cathodes was prevented over the test periods of from approximately 3 to 6 years except in one poorly conducting soil and in a very alkaline soil. Measurements of galvanic current and open- and closed-circuit potentials made on the experimental couples during the course of the test are interpreted in terms of the extent cathodic protection received. Measurements of the apparent current required for cathodic protection as indicated by current-potential curves are compared with the currents actually required to prevent corrosion.
\end{abstract}

\section{Introduction}

Prior to the present investigation, which was started in 1941, zinc anodes had been employed more or less experimentally by a number of corrosion engineers for the cathodic protection of iron and steel pipe lines in local regions with corrosive soils. Several successful installations $[1]^{1}$ had been described in the literature, but other reports of the use of zinc anodes were less favorable, raising the question whether differences in environment might not account for the reported differences in behavior. In order to study the effectiveness of zine for the cathodic protection of iron and steel in different soils, the National Bureau of Standards in 1941 organized a series of field tests in cooperation with eight pipe line companies. The plan called for the installation of eight test sites, selected to represent a diversity of soil conditions, of galvanic units, consisting of an iron or steel cathode connected to from one to three zinc anodes. By varying the number of anodes, the current density on the corresponding cathodes was subject to some control. At the conclusion of the test the couples were to be returned to the laboratory for measurement of the degree of protection provided and to obtain other pertinent information.

\footnotetext{
1 Figures in brackets indicate the literature references at the end of this paper.
}

Although measurement of the loss in weight of the steel cathodes after a given period of exposure would establish the degree of cathodic protection provided by the zinc anodes in the environments selected, it was planned also to make several electrical measurements as possible alternative indications of the protection obtained. Provision was made for measurement, whenever the opportunity offered, of galvanic currents and electrode potentials, and for study of the potential of the cathode as a function of applied current.

Subsequent to the installation of these experimental couples, a number of installations of zinc anodes on pipe lines have been made. In these recent installations attention has been directed chiefly toward maintenance of the most favorable environment around the anodes for the maximum output of current $[2,3,4]$.

\section{Properties of Soils at Test Sites}

The properties of the soils at the test sites, recorded in table 1 , indicate that the soils are highly diversified. The reaction of the soils ranges from the very acid Susquehanna clay, $\mathrm{pH} 4.3$, to the strongly alkaline Chino silt loam, $\mathrm{pH} \mathrm{9.2.} \mathrm{The} \mathrm{data} \mathrm{indicate} \mathrm{that} \mathrm{the} \mathrm{soils} \mathrm{cover} \mathrm{a}$ wide range of composition and total content of 
soluble salts. For example, in the Otero clay (site 74), calcium sulfate is present in high concentration, but in the silt loam at Albuquerque, N. M. (75), sodium sulfate predominates. The
Chino silt loam (76) is unique in containing sodium carbonate, the presence of which accounts for the relatively strong alkaline reaction of this soil (pH 9.2).

TABLE 1. Properties of the soils at the test sites

\begin{tabular}{|c|c|c|c|c|c|c|c|c|c|c|c|c|c|c|c|c|}
\hline \multirow[b]{2}{*}{ Site } & \multirow[b]{2}{*}{ Soil type } & \multirow[b]{2}{*}{ Location } & \multirow[b]{2}{*}{ Aeration } & \multirow[b]{2}{*}{$\mathrm{pH}$} & \multirow{2}{*}{$\begin{array}{l}\text { Resis- } \\
\text { tivity } \\
\text { at } \\
60^{\circ} \mathrm{F}\end{array}$} & \multirow{2}{*}{$\begin{array}{c}\text { Total } \\
\text { acidity } \\
\text { (mg-eq/ } \\
100 \mathrm{~g} \text { of } \\
\text { soil) }\end{array}$} & \multicolumn{10}{|c|}{ Composition of water extracts-milligram equivalents per $100 \mathrm{~g}$ soila } \\
\hline & & & & & & & $\mathrm{SiO}_{2}$ & $\begin{array}{l}\mathrm{Na}+\mathrm{K} \\
\text { as Na }\end{array}$ & $\mathrm{Ca}$ & $\mathrm{Mg}$ & $\mathrm{CO}_{3}$ & $\mathrm{HCO}_{3}$ & $\mathrm{Cl}$ & $\mathrm{SO}_{4}$ & $\mathrm{NO}_{3}$ & Other \\
\hline $71 \ldots$ & $\begin{array}{l}\text { Mahoning silt } \\
\text { loam. }\end{array}$ & $\begin{array}{l}\text { West A ustin - } \\
\text { town, Ohio. }\end{array}$ & Fair & 7.1 & $\mid \begin{array}{c}\text { ohm-cm } \\
2,582\end{array}$ & 4 & 0.37 & 0.22 & 0.37 & 0.28 & & 0.33 & 0.030 & 0.27 & 0.24 & \\
\hline $72 \ldots$ & $\begin{array}{l}\text { Papakating silty } \\
\text { clay loam. }\end{array}$ & Deerfield, Ohio.... & Very poor - & 7.2 & 762 & 17 & .34 & 3.11 & 7.49 & .95 & & & & 11.58 & & $\begin{array}{l}\text { Al, } 0.25 \\
\mathrm{Mn}, .40\end{array}$ \\
\hline $73 \ldots$ & $\begin{array}{l}\text { Wabash silty clay } \\
\text { loam. }\end{array}$ & East St. Louis, Ill_ & $\ldots$ do $\ldots . . .$. & 6.8 & 521 & 6 & .67 & 0.44 & 2.80 & .68 & & 1. 75 & 0.020 & 1.99 & & \\
\hline $74 \ldots$ & Otero clay loam & Rocky Ford, Colo & Fair ....... & 7.3 & 436 & 5 & .90 & 4. 72 & 18.42 & 4. 24 & & 0.77 & .38 & 26.22 & & \\
\hline $75 \ldots$ & Silt loam .......... & $\begin{array}{l}\text { Albuquerque, N. } \\
\text { Mex. }\end{array}$ & $\ldots$ do & 8.4 & 379 & Alkaline & .47 & 5.80 & 0.87 & 0.16 & & .56 & .70 & 5.58 & & \\
\hline $76 \ldots$ & Chino silt loam _. & Los Angeles, Calif & Good & 9.2 & 2,650 & $\ldots \mathrm{dc} \ldots$ & .40 & 1.54 & .065 & & 0.16 & 1. 23 & .068 & 0.15 & & \\
\hline $77 \ldots$ & $\begin{array}{l}\text { Susquehanna } \\
\text { clay. }\end{array}$ & Louisville, Miss ... & Fair....... & 4.3 & 9,390 & 42 & .30 & 0.39 & .14 & $\cdots$ & $\mid-\ldots$ & -n....... & .40 & .047 & 0.081 & . \\
\hline $78 \ldots$ & $\begin{array}{l}\text { Caddo fine sandy } \\
\text { loam. }\end{array}$ & Latex, Tex........ & Poor ...... & 4.5 & 821 & 24 & .70 & 1.06 & .18 & 0.31 & $\ldots$ & & .82 & .74 & & \\
\hline
\end{tabular}

a Analyses of water extracts by L. Schubert, Chemistry Division. National Bureau of Standards.

With respect to aeration, wide differences are exhibited. Marked reducing conditions, as shown by measurements of oxidation-reduction potential, are represented by the Papakating silt loam (72). The soil at the test site at East St. Louis, Ill. (73), is also very poorly aerated, the water table being close to the surface. Oxidizing conditions are represented by the test sites at Albuquerque, $\mathrm{N}$. Mex. (75), and Los Angeles, Calif. (76).

\section{Experimental Zinc-Steel Couples}

A zinc-iron couple for use in field tests should be so designed that the data obtained may be applied to practical installations. Although the circuit resistance of a small test couple will necessarily differ greatly from that of a practical installation, it can be shown that if the appropriate dimensions are maintained in a medium of large extent and with the same resistivity, the current densities on the cathodes will be the same for the two installations.

The design of the experimental cathode and the installation of the couple at the test sites were based on theoretical considerations and measurements of current distribution as affected by the form of the cathode, horizontal spacing, and depth of the cathode below the surface of the ground.
All of these measurements were made in a tank of such size relative to the size of the test couple that the effect of the walls and bottom of the tank on current distribution could be neglected. End effects were avoided by bending a steel rod in the form of an open ring, forming essentially what is known as a toroid or anchor ring (fig. 2). For distances from a small anode equal to or greater than the diameter of the ring, the maximum difference in current density over the cathode was about 10 percent. The effect of variations in the horizontal spacing between cathodes on current distribution was negligible at distances greater than the diameter of the ring. Similarly, at this distance from the surface, no effect of the surface on current distribution could be detected.

Cathodes for the field tests were constructed by bending a sufficient length of steel rod $0.5 \mathrm{in}$. in diameter to form a ring having an external diameter of 10 in. A small hole was drilled through one end of the curved rod, and, after the ring had been weighed, the end of a No. 14 rubber-covered copper wire was soldered into the hole. A coating of a bituminous material was then applied to the soldered joint. The surface area of the ring was $48 \mathrm{sq}$ in. Because field tests had shown that the composition of the low-carbon steels commonly 
used in the manufacture of pipe for underground service has a negligible effect on corrosion rate, no effort was made to secure steel conforming to some definite specification for the preparation of the cathodes, and steel that was readily available from stock was used.

Another problem in the design of a suitable experimental couple is the maintenance of definite ratios of the areas of zinc and steel throughout the duration of the test. This condition is difficult to produce in experimental couples, because the change in area of a small anode for a given rate of penetration by corrosion would be relatively greater than the change in area of the large anode in a practical installation for the same rate of penetration. However, by exposing only the base of a cylindrical zinc anode to the soil, the area of the zinc and hence the zinc-steel area ration could be held reasonably constant. This result was accomplished by covering each cylindrical zinc anode with a housing, which consisted of a wide-mouthed glass bottle, slightly larger in diameter than the anode, from which the base had been removed. With a zinc cylinder of sufficient weight, firm contact with the soil was assured, the cylinder being free to move downward as its base corroded.

The cylindrical anodes were $1.75 \mathrm{in}$. in diameter and $3.75 \mathrm{in}$. in height. The exposed area of the base of the anodes was $2.4 \mathrm{sq}$ in. After the anodes had been weighed, the cylindrical surface was coated with a bituminous paint to prevent local corrosion, and a length of insulated copper wire was soldered to one end. The nominal percentage composition of the zinc used for the anodes was: $\mathrm{Pb}, 0.007$; Fe, 0.005; Al, 0.00; Zn, 99.98 (by difference).

The plan of installation of the couples at the test sites is shown in figure 1. As is shown in the figure, the electric circuit was completed by means of binding posts attached to a copper strip. To protect the terminals from corrosion, the copper strip was placed in a glass bottle from which it could be removed when electrical measurements were to be made.

PLAN OF TRENCH

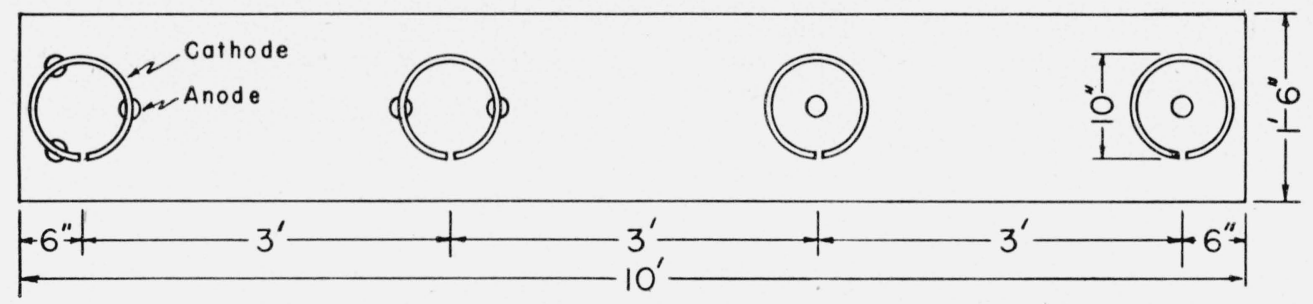

ELEVATION OF TRENCH

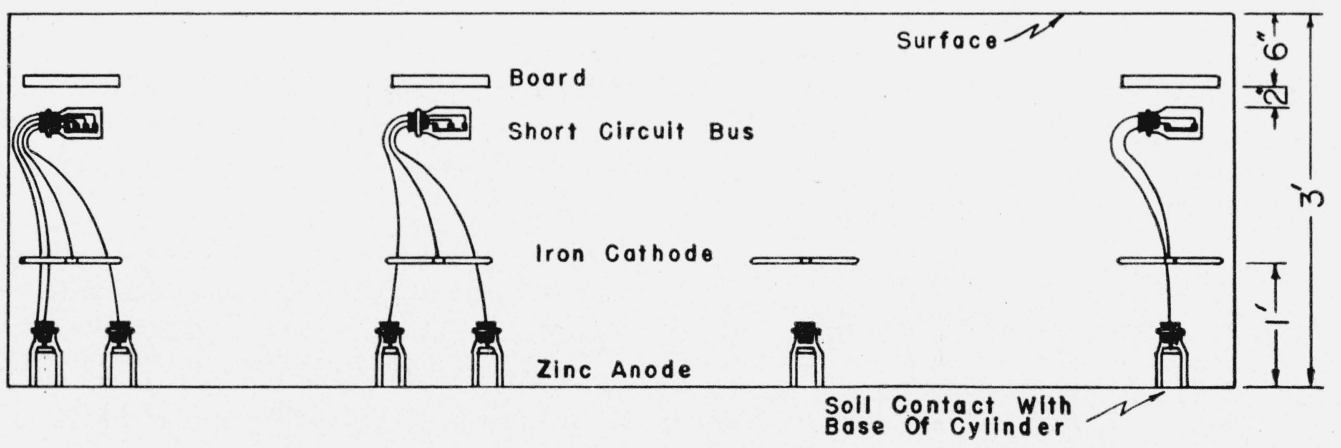

FiguRE 1. Arrangement of zinc-steel couples at the test sites. 


\section{Cathodic Protection as by Indicated Corrosion Measurements}

The losses in weight and the depths of the deepest pits on the steel cathodes connected to the zinc anodes are shown in table 2 , together with similar data for the unconnected steel rings and zinc cylinders. It is evident that over the test periods of from 3 to nearly 6 years, practically complete protection was obtained at six of the eight test sites, namely 71 to 75 , inclusive, and 78 . Although a zinc-steel area ratio of $1: 20$ was sufficient for protection at sites 74,75 , and 78 , an area ratio of $1: 10$ was required at sites 71,72 , and 73 . The condition of the connected and unconnected steel rings and the bases of the zinc cylinders from sites 75 and 78 is shown in figure 2 .

TABLE 2. Weight losses and maximum pit depths on connected and unconnected electrodes

$P$, Deepest pit less than 6 mils; $M$, shallow metal attack - no definite pits; $S$, uniform corrosion-no reference surface for pit measurements

\begin{tabular}{|c|c|c|c|c|c|c|c|c|}
\hline \multicolumn{2}{|r|}{ Site } & \multirow{2}{*}{$\begin{array}{l}\text { Duration } \\
\text { of exposure }\end{array}$} & \multirow{2}{*}{ State of couple } & \multirow{2}{*}{$\begin{array}{l}\text { Number of } \\
\text { zinc anodes }\end{array}$} & \multicolumn{2}{|c|}{ Weight loss } & \multirow{2}{*}{$\begin{array}{l}\text { Maximum } \\
\text { penetration } \\
\text { of cathode }\end{array}$} & \multirow{2}{*}{$\begin{array}{l}\text { Effective- } \\
\text { ness of pro- } \\
\text { tection a }\end{array}$} \\
\hline No & Location & & & & Cathode & $\begin{array}{l}\text { T'otal loss } \\
\text { of anodes }\end{array}$ & & \\
\hline
\end{tabular}

SITES AT WHICH PROTECTION WAS OBTAINED WITH A 1:20 ZINC-STEEL AREA RATIO

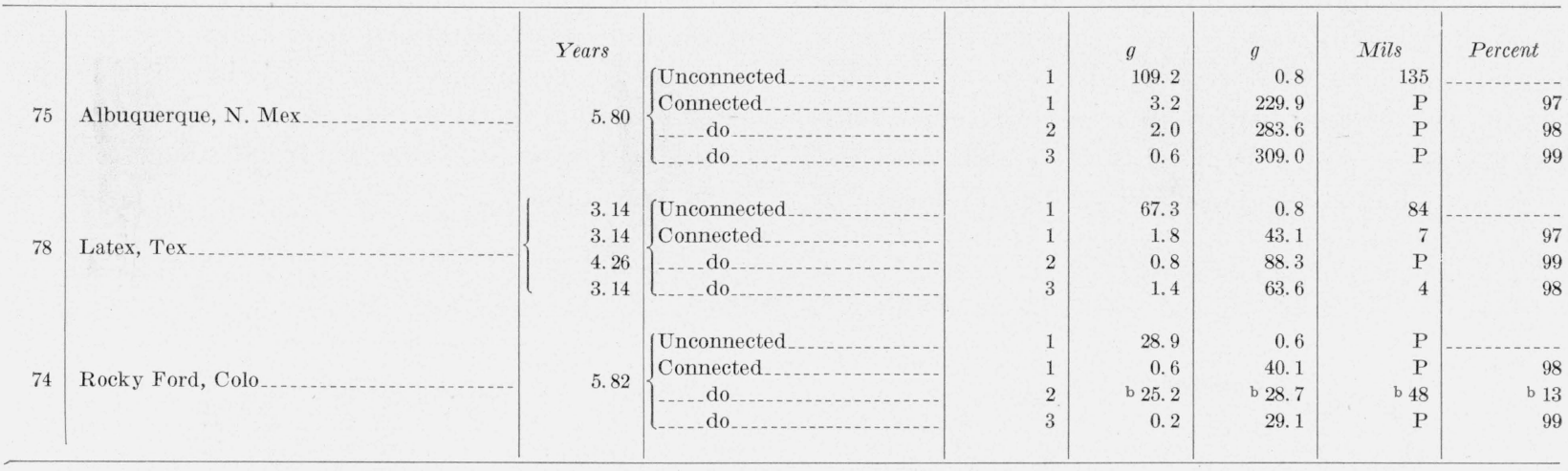

SITES AT WHICH PROTECTION WAS OBTAINED WITH A 1:10 ZINC-STEEL AREA RATIO

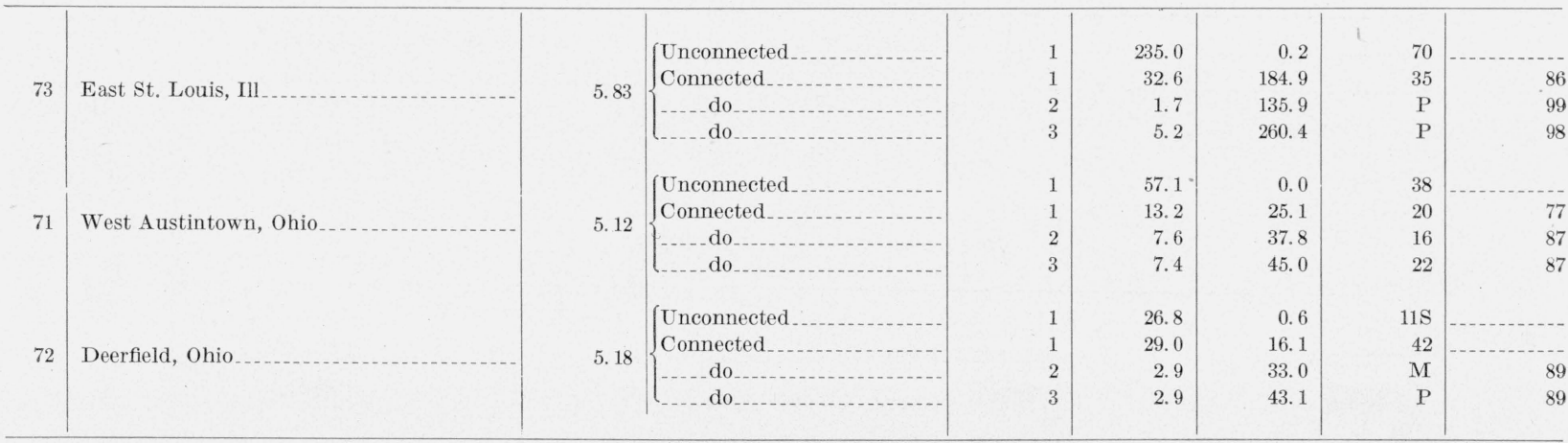

SITES AT WHICH INCOMPLETE PROTECTION WAS OBTAINED EVEN WITH A 1:6.7 ZINC-STEEL AREA RATIO

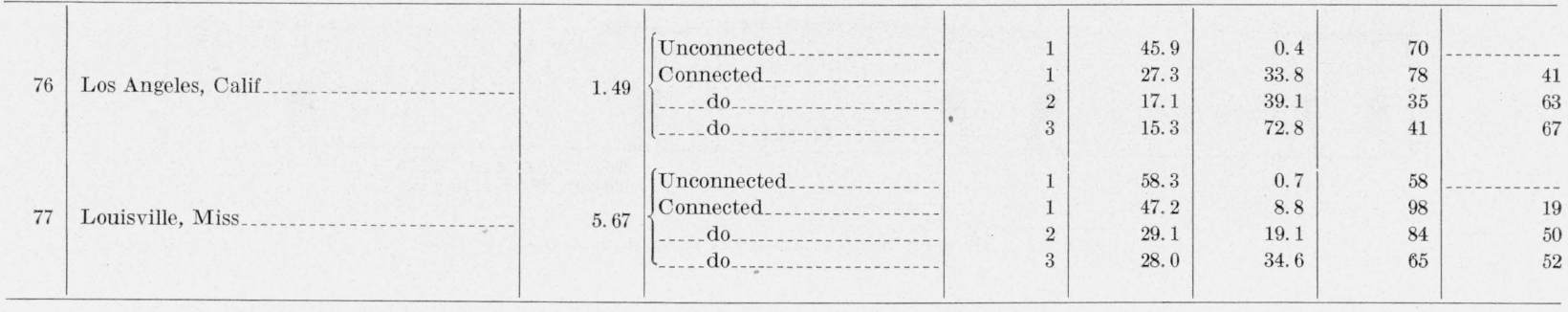

a Based on weight loss of unconnected ring.

b Couple on open circuit for an indefinite period. 

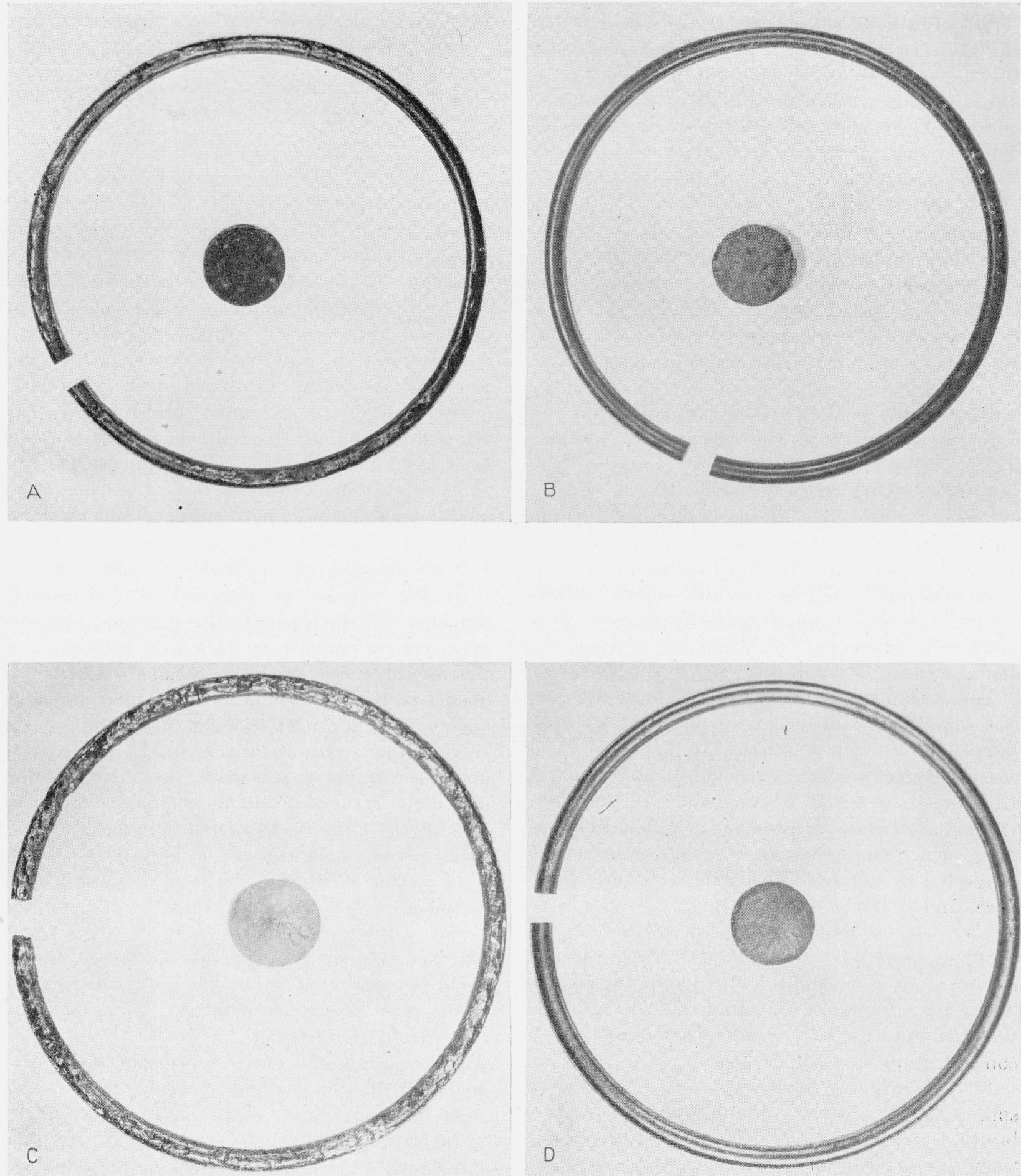

Figure 2. Condition of connected and unconnected steel cathodes and zinc anodes at two test sites.

$A$, Unprotected steel ring and zine cylinder exposed at site 78 for 3.1 years; $B$, ring connected to zine anode at site 78 for 3.1 years. Zn-Fe area-ratio $1: 20$; $C$. unprotected steel ring and zine eylinder exposed at site 75 for 5.8 years; $D$, ring connected to zine anode at site 75 for 5.8 years. Zn-Fe area-ratio $1: 20$. 
The primary environmental factors that affected the behavior of the zinc anodes are indicated by the data of table 1 . The soil properties that appear to have the most inhibitive effect on the anodes are high resistivity and high alkalinity. The fact that protection was not obtained at site 77 is no doubt caused by the high specific resistance of the soil, 9,370 ohm-cm, at this site. Although the relatively high resistivity of soil $76(2,650$ ohm-cm) was probably an important factor in the poor performance of the zinc anodes at this site, the high concentration of hydroxyl ions in this soil, indicated by the $\mathrm{pH}$ value of 9.2 , probably tended to inhibit the galvanic corrosion of the zinc anodes. With regard to the remaining soils, it would seem that the composition of the water soluble material was unimportant, providing the resistivity of the soil was relatively low. Improvement in the performance of zinc anodes in poorly conducting soils and in strongly alkaline soils deficient in chloride and sulfate ions can probably be obtained by surrounding the anodes with materials, such as calcium sulfate, which produce soluble corrosion products of zinc. This practice is advocated by Mudd [3], Morgan [5], and others.

The data obtained from site 72 throw light on the somewhat controversial subject of whether cathodic protection is practical in highly reducing environments in which microbiological activity is an important factor in corrosion. In such environments it is assumed that high-resistance oxide films, which normally cover cathodic areas, are converted to sulfide films of relatively low resistance, and that the effect of this conversion is to cause a large proportion of the protective current to be bypassed by the cathodic areas, thereby requiring an abnormally high current for protection. By referring to the data in table 1, it is seen that the soil at site 72 contains a relatively high concentration of sulfate ions. The reducing nature of this soil is shown by the presence of sulfide in the corrosion products of steel at this location and also by measurements of the oxidation-reduction potential. Under these conditions it is noteworthy that adequate protection of the steel cathodes was obtained with a moderate area-ratio of zinc to steel.

\section{Cathodic Protection as Indicated by Electrical Measurements}

\section{Galvanic Currents and Open-and-Closed- Circuit Potentials}

The data reported in table 3 consist of measurements made after various periods of exposure, of galvanic currents, potentials of the couples on closed circuit, and open-circuit potentials of the steel rings and zinc cylinders. Currents were measured by the zero-volt-loss method $[6,7]$, the $I R$ drop in the millimeter being compensated by an equal and opposite voltage by means of a battery and a variable resistance. Potential measurements were measured with a potentiometer-voltmeter. A copper--copper sulfate half cell placed about 10 feet from the couple was used as a reference electrode. After measuring the galvanic currents and the closed-circuit potentials of the couples, the circuits werè opened for 15 to 20 minutes, and the open-circuit potentials of the zinc anodes and steel cathodes were measured.

In the absence of polarization and mutual influence of the anodes, the galvanic currents produced by connecting, to a steel cathode, one, two, or three zinc anodes in parallel would be expected to be in the same ratio as the number of anodes. An approach to this ratio is shown by the currents that were measured at site 75 immediately after the installation was made, the currents standing in the ratio of $1: 2: 2.6$. Similarly, the averages of the currents measured at site 72 for the entire period of the test are in the ratio $1: 1.9: 2.7$. As a matter of interest, the total losses in weight of the respective numbers of zinc anodes for the 5 -year test period are in the ratio $1: 2.0: 2.7$, showing that the entire loss in weight of the anodes could be accounted for by the galvanic currents, as has been previously indicated. The fact that the currents were not in the exact ratio of $1: 2: 3$ indicates some influence between the anodes connected to the same cathode.

At the test sites where polarization of the cathodes was marked, the couples that contained three anodes produced little, if any, more current than the couples that contained only two anodes. Furthermore, two anodes often produced considerably less than twice the current produced by 
TABLE 3. Potential and current measurements

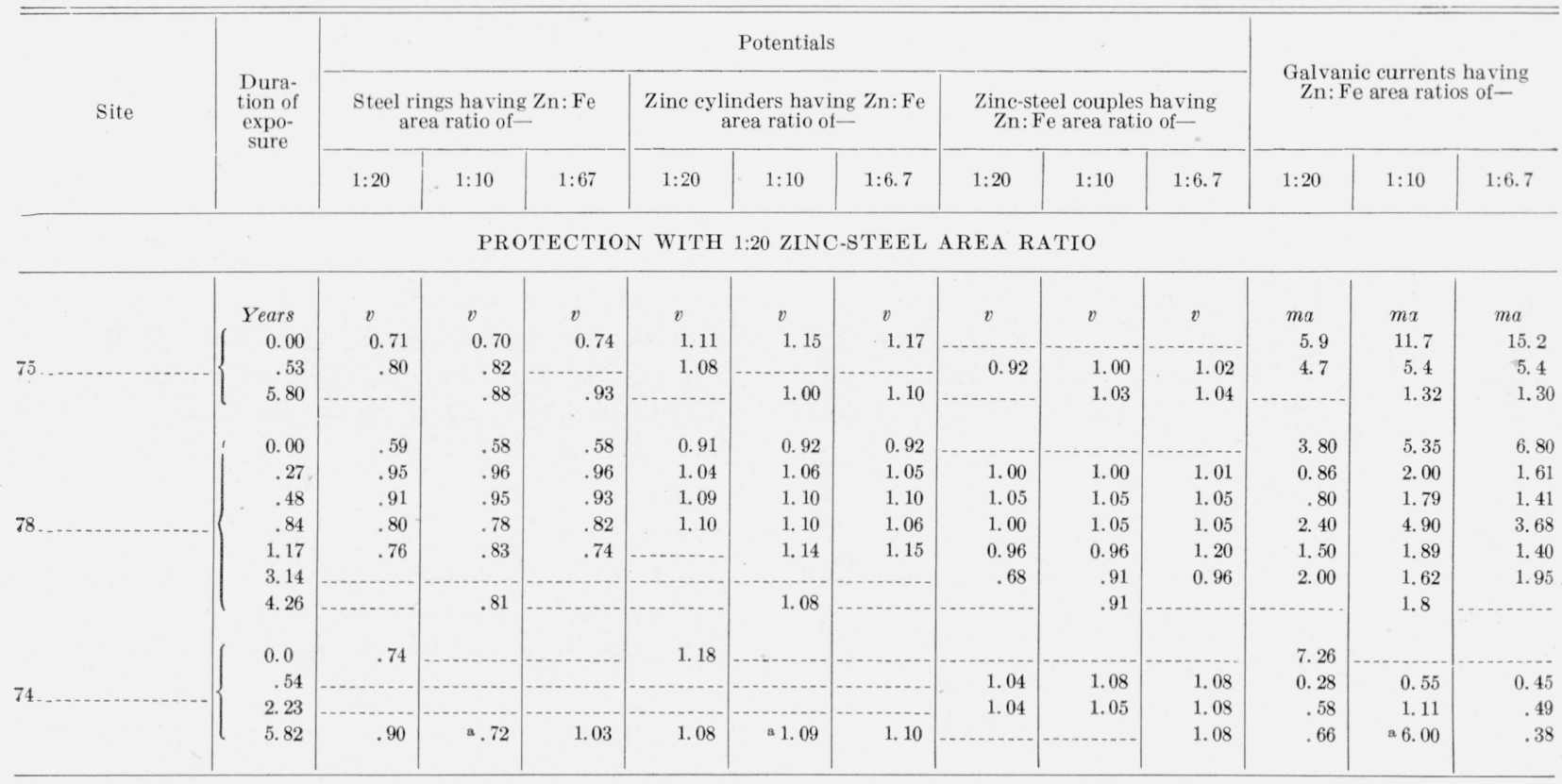

PROTECTION WITH 1:10 ZINC-STEEL AREA RATIO

\begin{tabular}{|c|c|c|c|c|c|c|c|c|c|c|c|c|c|}
\hline \multirow{3}{*}{73.} & 0.0 & & & & & & & & & & 2. 6 & 4. 6 & 4. 60 \\
\hline & .68 & 0.94 & 0.95 & 0.85 & 1. 10 & 1. 11 & 1. 14 & 1. 01 & 1.03 & 1. 03 & 0.58 & 1.00 & 1.02 \\
\hline & 5.83 & .68 & .84 & .68 & 1.05 & 1.09 & 1.06 & -.... & 0.90 & 0.76 & 3.45 & 2.40 & 5.00 \\
\hline \multirow{5}{*}{71.} & 0.0 & .59 & .58 & .60 & 1. 09 & 1. 10 & 1. 10 & & & & 0.44 & 0.48 & 0.66 \\
\hline & .32 & .62 & .55 & .60 & 1. 11 & 1. 12 & 1. 13 & 0.76 & .80 & .94 & .93 & 1. 33 & 1. 30 \\
\hline & .77 & ..... & ...... & ..... & . & ..... & ..... & .79 & .84 & .92 & .62 & 1.15 & 1. 48 \\
\hline & 3.02 & .50 & .58 & .56 & 1.04 & 1. 26 & 1. 28 & .55 & .69 & .73 & .43 & 1.12 & 2. 00 \\
\hline & 5.12 & .63 & .74 & .93 & 1. 04 & 1.08 & 1.11 & .76 & .86 & 1.00 & .21 & 0.27 & 0.35 \\
\hline \multirow{6}{*}{72.} & 0.0 & .73 & .73 & .73 & 1.14 & 1.14 & 1.14 & & & & .73 & 1.46 & 2. 65 \\
\hline & .31 & .78 & .85 & .75 & 1.02 & 1,06 & 1.05 & .79 & .89 & .83 & .24 & 0.41 & 1. 14 \\
\hline & .73 & .76 & .80 & .77 & 1. 02 & 1.07 & 1.05 & .77 & .83 & .82 & .35 & .66 & 1. 17 \\
\hline & 1.04 & .71 & .76 & .76 & 1. 02 & 1. 06 & 1.06 & .72 & .80 & .81 & .54 & .97 & 1.34 \\
\hline & 3.01 & .62 & .71 & .73 & 0.91 & 1.05 & 1. 06 & .64 & .72 & .77 & .52 & .84 & 0.08 \\
\hline & 3.18 & .58 & .63 & .75 & .82 & 1.08 & 1.04 & .58 & .65 & .79 & .14 & .31 & .49 \\
\hline
\end{tabular}

INCOMPLETE PROTECTION

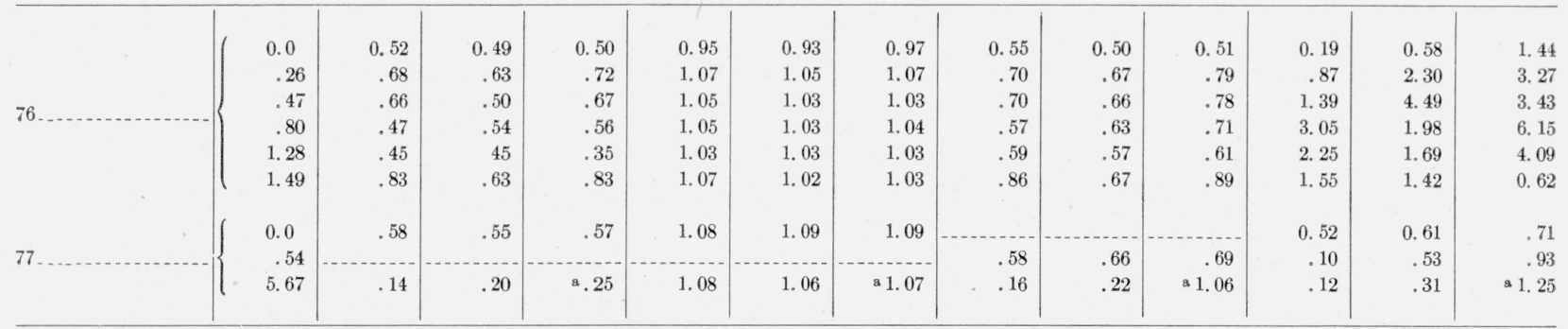

a Couple found on open circuit. 
one anode. These observations are illustrated by the ratio of the average currents at site 78 for one, two, and three anodes, namely, $1.0: 1.5: 1.5$. As would be inferred from this relation, cathodic protection was readily accomplished at this site, a zinc-iron ratio of $1: 20$ being sufficient to prevent corrosion of the cathode (table 2 ).

The open-circuit potentials of the cathodes are seen to be highly variable, ranging at various sites from 0.14 to 0.96 volt. This is in marked contrast to the potentials of the zinc anodes, which, with a few exceptions, were remarkably constant. The marked differences in the potentials of the steel cathodes can be interpreted in terms of the local cell theory of Müller [8]. According to Müller, the potential of a self-corroding surface is given by the equation.

$$
E=E_{A} \frac{R c}{R c+R a}+E_{C} \frac{R a}{R c+R a},
$$

where

$E=$ observed potential

$E_{A}=$ potential of the anodic areas

$E_{C}=$ potential of the cathodic areas

$R c=$ resistance of the cathodic film

$R a=$ resistance of the anodic areas, i. e., at pores.

This equation shows that if the resistance of the cathodic areas is very high relative to the resistance of the anodic areas, the potential of the anode only, $E_{A}$, is measured, and vice versa.

On the basis of Müller's equation one might reasonably interpret the relatively high values of potential measured in soils $73,74,75$, and 78 as indicating that the potential of the anodic areas, $E_{A}$, was being approached. Similarly, the relatively low values for the potential of the rings in soils 76 and 77 would be taken to indicate that these values were influenced to a somewhat greater extent by the potential of the local cathodes $E_{C}$.

According to the criterion of Mears and Brown [9] for cathodic protection, namely, that corrosion is prevented when the potential of the local cathodes is brought to the open-circuit potential of the local anodes, one might infer that a slight increase in the relatively high potentials of the iron cathodes in soils $73,74,75$, and 78 would be sufficient to prevent corrosion, because the observed potentials are already probably very close to the open-circuit potentials of the local anodes.
By the same reasoning, a proportionately greater change in the nobler potentials of the cathodes in soils 76 and 77 would be necessary to prevent corrosion.

By comparing the open-circuit potentials of the eathodes in soils $73,74,75$, and 78 with the corresponding closed-circuit potentials, it can be seen that by connecting the zinc anodes to the steel cathodes, the potentials of the latter were brought close to the potentials of the zinc anodes. As these latter potentials are almost certainly more anodic than the potentials of the local anodes on the steel rings, the criterion for cathodic protection suggested by Mears and Brown has apparently been satisfied. However, because of the inclusion of some IR drop, the values of closed-current potential indicated are probably somewhat greater than the true potentials of the local anodes. Because of the more cathodic potentials of the steel rings at sites 76 and 77 , small changes in potential are seen to have been insufficient to polarize the rings to the potentials of the local anodes, and as a consequence, corrosion was not prevented. The relatively low closed-circuit potentials of the couples at sites 76 and 77 indicate that polarization of the zinc anodes was also an important factor in the failure to achieve cathodic protection in these soils.

\section{Current-Potential Curves for the Steel Cathodes}

In addition to the electrical measurements described in the preceding section, current-potential curves for the cathodes were obtained at most of the test sites. The relation between the potential of a corroding element and the applied current has been suggested as a practical means of measuring the current required for the protection of iron and steel cathodically. As increasing currents are caused to flow toward a corroding surface, the potential remains constant over a range of currents after which the potential changes in proportion to the logarithm of the current. Consequently, if the values of potential are plotted on the vertical axis against the logarithm of the corresponding currents on the horizontal axis, the points up to a certain value of current will lie along a horizontal line. Beyond this value of current and after more or less transition, the points fall along a second straight line having an appreciable slope. The current corresponding to the point at which 
the potential departs from the horizontal relation and follows the curve for hydrogen overvoltage has been taken by Evans, Bannister and Britton [10], Pearson [11], and Ewing [12] as the minimum current that will prevent corrosion at least under the particular experimental conditions. However, as many current-potential curves depart considerably from the ideal curve, the interpretation of current-potential curves generally in terms of the current required for protection is uncertain. As it seemed probable that at least one of the three cathodes at each test site would be just protected cathodically, comparison of the values of the minimum protective current estimated from the current-potential curves and the galvanic currents that flowed to such protected cathodes would indicate the manner in which current-potential curves had best be interpreted in terms of the current required for cathodic protection.

Before proceeding with the interpretation of the current-potential curves of the experimental couples, it is preferable to consider similar curves obtained under conditions that permit direct comparison between the values of the protective current indicated by the curves and the currents actually required to prevent corrosion. In figure 3 are shown current-potential curves for steel electrodes in contact with two soils contained in a specially designed corrosion cell. The electrodes of the cell consisted of two segments cut from a disk of low-carbon sheet steel. The seg- ments, separated by a thin bakelite strip, were placed side by side in the end of a Bakelite tube having the same internal diameter as the disk from which the segments were cut. The segments were aerated differentially by covering one segment with soil which, after being moistened had been mechanically worked to remove all air spaces, the other segment being covered with soil in its natural condition. After bringing the soil to a definite moisture content, the cell was placed on closed circuit. The potential of the electrodes connected externally was measured free of $I R$ drop by the method of Hickling [13] the measurements being made during very short interruptions of the polarizing current. The reference electrode was so placed that further separation from the test electrodes being measured had no effect on the observed values. In addition to the potential of the electrodes, the cell current was measured as the applied current was increased, a "zero-resistance" milliammeter being used. The open-circuit potentials of the anode initially and after reduction of the cell current to zero are indicated in the figure for cells $A$ and $B$.

In addition to the horizontal part previously referred to, the curves are seen to consist of two straight sections that differ in slope. Taking the lower curve to represent the overvoltage curve for evolution of hydrogen, it would seem to follow that the middle curve represents the cathodic reduction of oxygen. This interpretation of cur-
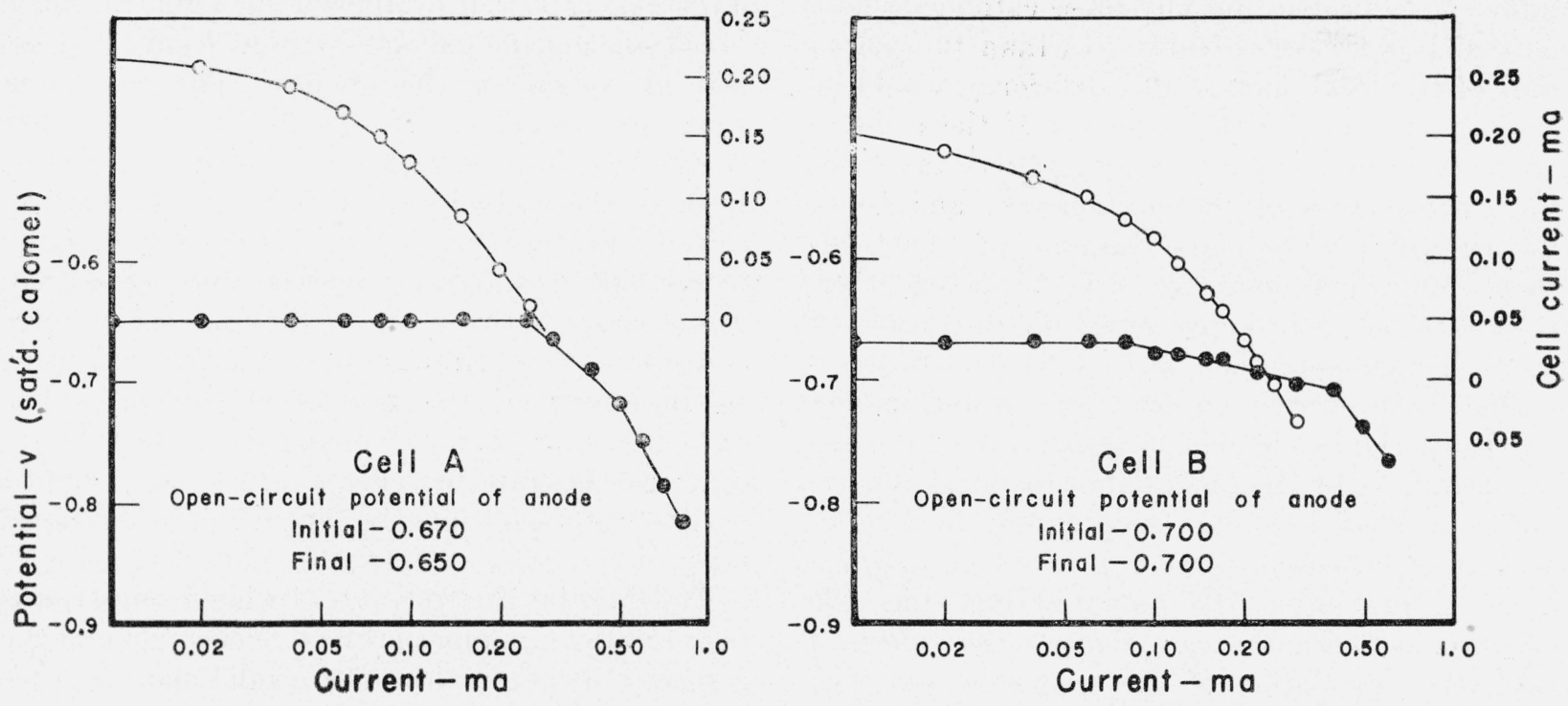

FIgURE 3. Current-potential relation for differential-aeration cells with steel electrodes.

- Potential; $\bigcirc$ cell current. 
rent-potential curves for the cathode is essentially that of Evans, Bannister, and Britton [10].

It will be noted in the curves representing the behavior of cell $A$ that the value of applied current that was required to reduce the cell current to zero coincided exactly with the discontinuity in the current-potential curve. In cell $B$, on the other hand, considerably more current was required to bring the cell current to zero than is indicated by the discontinuity in the currentpotential curve. By referring to the values of the open-circuit potentials of the anodes, it is seen that if the open-circuit potential at the anode corresponds to the over-all potential of the combined anode and cathode, as in cell $A$, the protective current is indicated by the first discontinuity in the current-potential curve. However, if the over-all potential assumes lower or more cathodic values, the first discontinuity indicates a lower value of applied current than that actually required to prevent corrosion. Incidentally, it should be noted that no more current was required to reduce the cell current to zero than that which flowed originally in the corrosion circuits.

On the basis of a priori considerations and the laboratory measurements that have been described, it seems reasonable to consider the minimum protective currents as corresponding to the departures of the potential from the constant values indicated by the horizontal parts of the curves. Although these values of current would be insufficient to protect initially those cathodes whose potentials were considerably less than the potentials of the local anodes, this deficiency would be compensated for by the tendency of the current, applied continuously over a long period, to reduce the corrosiveness of the environment and hence the current requirement. Because of this tendency, for which evidence will be given later, the value of current indicated by the discontinuity in the current-potential curve might actually overestimate the current required over a long period for the special case in which the observed potential is determined by the potential of the local anodes.

The method used in obtaining the first series of current-potential curves, at sites 71 and 72 , involved measuring the potential including the $I R$ drop between the cathode and the reference electrode, calculation of the resistance for each value of applied current by observing the change in potential corresponding to an increment of cur- rent, and subtraction from each value of $E+I R$ the calculated value of the $I R$ drop. All subsequent measurements were made with the null method described by Pearson [ $\left.{ }^{11}\right]$, in which the $I R$ drop is balanced out of the circuit and the true potential read directly. Typical currentpotential curves obtained with the cathodes of the zinc-steel couples are shown in figure 4 .

In the curves obtained at most of the test sites, the middle linear sections referred to in the discussion of figure 3 are well defined. It is possible that this section is obscured in the curves for sites 71 and 72 because of the successive changes in potential, which may have been required to eliminate the local currents in corroding areas in which, because of their geometrical configuration, the protective current density was not readily attained.

For comparison with the values of the minimum protective current obtained from the currentpotential curves, the average galvanic currents that flowed toward the protected cathodes were calculated from the following sources of data: (1) Periodic direct measurements of current, (2) losses in weight of the unconnected iron rings, and (3) losses in weight of the connected zine anodes. The total quantity of electricity that flowed in each couple during the test period was first calculated, and from these values the average currents were obtained. Fortunately, the losses in weight of the unconnected zinc anodes were very low (table 2) so that no appreciable error was made in calculating the galvanic current from the gross loss in weight of the anodes. The calculated values of average current are shown in table 4 for comparison with the minimum protective currents. Because the cathodes at sites 73 and 75 had received cathodic protection for nearly 6 years before the protective currents were measured, comparisons between the minimum and average currents at these sites are not valid for evaluating the accuracy of the protective currents. The data for these sites are included in the table in order to illustrate the effects of time and current on the protective currents, which will be discussed later.

The data for the test sites at which comparisons between the minimum protective currents and the respective average currents are valid, namely, sites 71,72 , and 78 , are seen to be of the same order of magnitude, the average currents being generally 

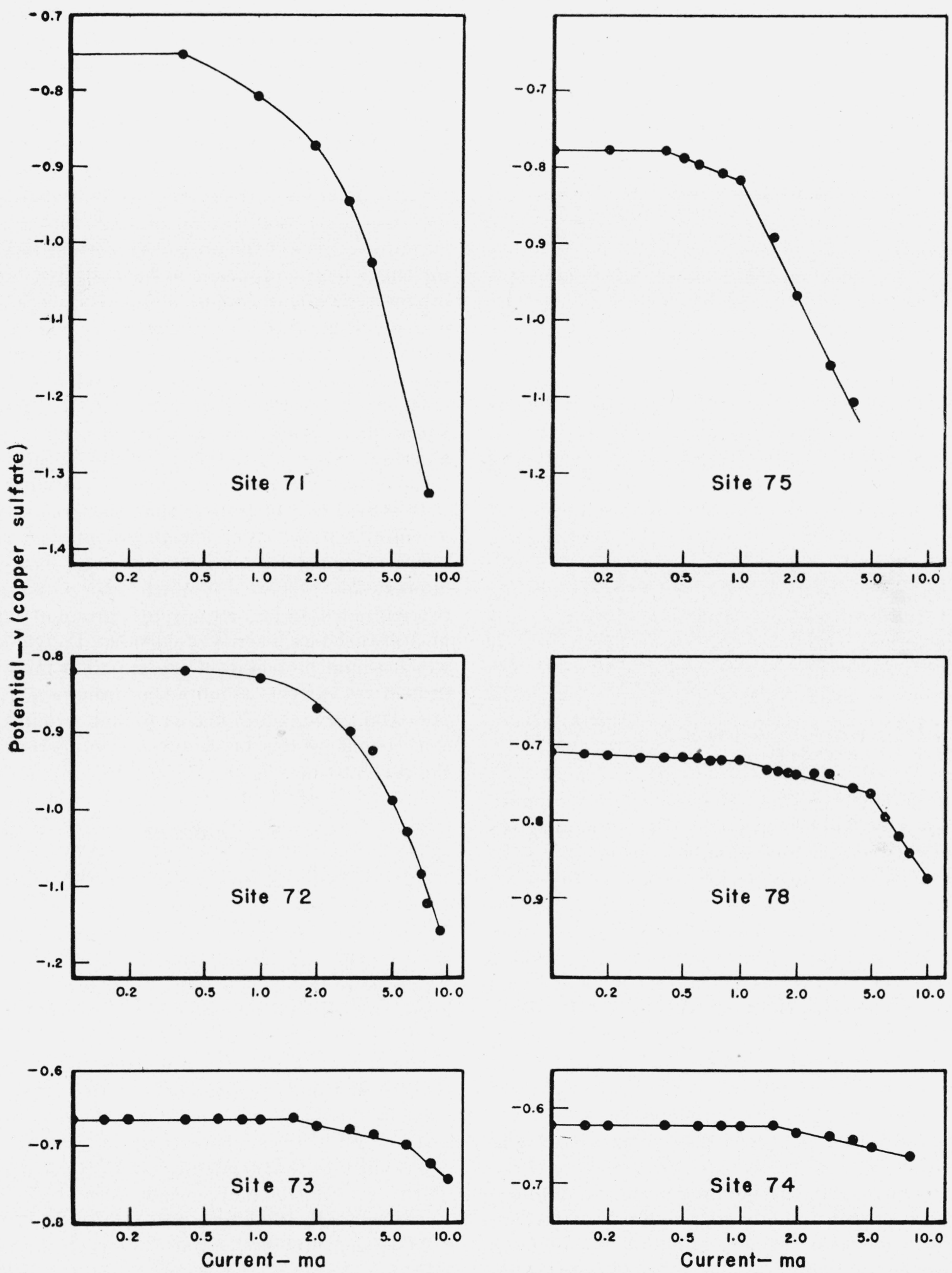

Figure 4. Current-potential curves of the cathodes of the zinc-steel couples. 
TABLE 4. Comparison of minimum protective currents as indicated by current-potential curves with calculated values as average current

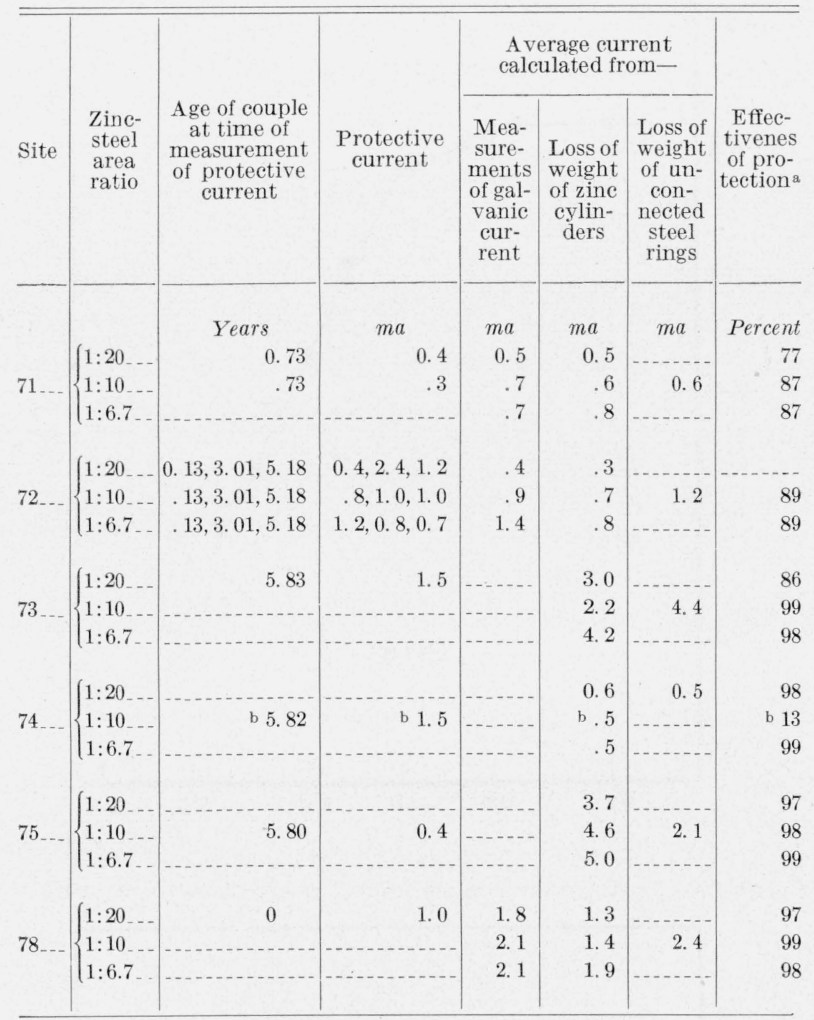

a Based on weight of unconnected specimen.

b Couple found on open circuit.

somewhat greater than the respective minimum values, as would be expected. This general agreement between the minimum and average values of current does not necessarily mean that the point on the current-potential curve at which the potential of the cathode departs from the constant potential indicates the value of the applied current that is just sufficient to reduce the corrosion currents to zero. In fact, it is altogether possible that considerably higher currents might have been required to effect this result initially. Prevention of corrosion at values of applied current somewhat less than the initial corrosion currents could readily occur if current applied over a long. period of time so reduced the corrosiveness of the environment that the minimum current requirement was correspondingly reduced. In other words, while possibly underestimating the quantity of current initially necessary to eliminate the current associated with corrosion, the method of estimating the protective current gives due weight to the current-time effect in reducing the current required for protection.

Evidence that the continuous application of current cathodically tends to reduce the current required for protection is afforded by the data for site 75 (table 4) in which it is seen that after nearly 6 years the protective current is only from onetenth to one-fifth of the average current, depending on the data used in calculating the average currents. Even if the protective current reported for this site is considered to be indicated by the intersection of projections of the horizontal part and the straight section of greatest slope (fig. 4), the value of the protective current estimated in this manner would only be doubled. Other evidence of the reduction in the required current with time is afforded by the data for site 73 , and to a certain extent by the data for site 72 , although these latter data are somewhat inconsistent.

It is realized, of course, that the procedure of attempting to interpret current-potential curves in terms of calculated values of average current is approximate at best. A much more satisfactory procedure would be to apply to a group of experimental cathodes a series of currents, the values of which would be based on the apparent minimum protective current as obtained from a currentpotential curve. As a matter of fact, two installations based on this procedure are in operation at the present time.

\section{Summary}

The cathodic protection of steel by means of zinc anodes has been investigated in eight soils. The cathode of the experimental galvanic couple was a steel ring having an area of $48 \mathrm{sq}$ in. to which were connected from one to three zinc anodes to provide different area ratios of zinc to steel. In six of the eight environments, corrosion of the steel cathodes was prevented over the test periods of from approximately 3 to 6 years, although a greater area of zinc was required in certain soil environments than in others. The soil conditions that tended to inhibit the corrosion of the zinc anodes galvanically were high resistivity and high alkalinity.

Measurements of electrode potentials are interpreted in terms of the extent to which cathodic protection was provided. The increase in potential, which resulted when one or more zinc anodes 
were connected to the iron rings, was found to indicate prevention of corrosion only for those cathodes whose potentials were already strongly anodic with respect to the reference electrode. Cathodes whose open-circuit potentials were less anodic were not protected when connection to zinc anodes produced similar changes in potential.

The minimum protective currents as obtained from current-potential curves for the cathodes were of the same order of magnitude as the average current of the galvanic couples calculated from direct measurements of current, from the loss in weight of the zinc anodes, and from the loss in weight of the unconnected steel rings. The general agreement between these values of the average current is interpreted as indicating that in the environments studied no more current is required for protection than is equivalent to the loss in weight produced by normal corrosion.

The authors gratefully acknowledge the material assistance received from the following individuals who cooperated in this project, either by providing the test sites, assisting in the installation of the tests, making the various electrical measurements, or by offering helpful suggestions relative to various phases of the investigation: C. B. Abbot, Colorado Interstate Gas Co.; C. L. Brockschmidt, formerly of Mississippi River Fuel Corp.; M. V. Carmichael, Southern Natural Gas Co.; Guy Corfield, Southern California Gas Co.; R. F. Hadley, Susquehanna Pipe Line Co.; Charles Kasper, formerly of the National Bureau of Stand- ards; K. H. Logan, Cast Iron Pipe Research Association; D. W. Martin, Public Service Co. of New Mexico; G. R. Olson, United Gas Pipe Line Co.; G. I. Rhodes, Ford, Bacon and Davis Co.; Charles Turner (deceased), East Ohio Gas Co.

The authors are especially indebted to K. H. Logan for installing the tests, to R. F. Hadley for making possible the frequent electrical measurements made at sites 71 and 72 , and for use of special electrical equipment, and to Guy Corfield and G. R. Olson for the numerous electrical measurements which they provided.

\section{References}

[1] G. I. Rhodes, Cathodic protection or electrical drainage of pipe lines, Monograph, Natural Gas Dept. Am. Gas Assn. (1935).

[2] C. L. Brockschmidt, Elec. News (Petroleum Ind. Elec. Assn.) 11, 31 (1942).

[3] O. C. Mudd Elec. News (Petroleum Ind. Elec. Assn.) 13, 11 (1943).

[4] H. W. Wahlquist, Corrosion 1, 119 (1945).

[5] C. L. Morgan, Petroleum Engr. 16, 196 (1945).

[6] Carl Hering, Trans. Am. Inst. Elec. Engrs. 31, 1949 (1912).

[7] R. H. Brown, and R. B. Mears, Trans. Electrochem. Soc. 74, 15 (1938).

[8] W. J. Muller, Trans. Electrochem. Soc. $\boldsymbol{7 6}, 167$ (1939).

[9] R. B. Mears and R. H. Brown, Trans. Electrochem. Soc. 74, 35 (1938).

[10] U. R. Evans, L. C. Bannister, and S. C. Britton, Proc. Royal Soc. (London) 131, 355 (1931).

[11] J. M. Pearson, Trans. Electrochem. Soc. 81, 485 (1942).

[12] S. Ewing, Proc. Am. Gas Assn. 613 (1940).

[13] A. Hickling, Trans. Faraday Soc. 33, 1540 (1937).

Washington, October 24, 1947. 